\title{
The effect of sales promotions characteristics on brand equity
}

\author{
Bahram Jabarzadeh Karbasi $^{\mathrm{a}^{*}}$ and Ali Jafari $\operatorname{Rad}^{\mathrm{b}}$
}

${ }^{a}$ Master of Business Management, Researcher at the ETKA Research and Development Center ${ }^{b}$ Master of administration management, Islamic Azad University, Kerman branch, Iran

\section{H R O N I C L E}

Article history:

Received March 202014

Accepted 28 July 2014

Available online

August 62014

Keywords:

Sale Promotions

Brand Equity

ETKA

Chain Stores

Iran

\section{A B S T R A C T}

In the recent years, retail industry in Iran has faced an increasing competition and this has encouraged the managers of chain stores to find ways to differentiate their own companies. One of the influential factors in this field is brand equity. Concerning this issue, the aim of this paper is to examine the effectiveness of sale promotions on the brand equity of ETKA chain stores. Therefore, a sample of 500 people among the customers of these stores in Tehran was examined. The achieved information obtained from the questionnaire was analyzed through structural equation modeling. The results showed that monetary and non-monetary promotions could influence on brand association, brand awareness and the perceived quality. On the other hand, it came out that brand association and the perceived quality are influential on brand loyalty. At last, a few suggestions were presented based on the results of this research.

\section{Introduction}

Many believe consider brand equity as one of the essential factors for any firm to reach a suitable position in the industry (Keller \& Lehmann, 2006; Keller, 2007). Brand equity is the most important desirability made by a product through brand (Baumgarth \& Schmidt, 2010). Brand equity is among the famous concepts of marketing reviewed and analyzed during the last decade (Yoo \& Donthu, 2001). Brand equity plays strategic and significant role and it plays in attaining competitive advantages (Wang, et al., 2007; Calvo-Porral, et al., 2013). Brand increases the firm's value by developing and concentrating on the awareness and knowledge so that it keeps current customers informed bout products and services (Kim \& Kim, 2005). Brand can be described as a mechanism to oblige both the buyer and seller on a long-term relationship (Simon \& Sullivan, 1993). Therefore, it can act as a defensive marketing instrument to maintain the current customers and as an aggressive one to attract new customers (Sweeney \& Swait 2008; Seo \& Jang, 2013). Since brand equity is reckoned as a measuring index of the effectiveness of brand strategies (Lin \& Kao, 2004), the focus on this issue that how marketing activities can increase or decrease brand equity is of highest significance. In the early 
years of 1980s, brand equity was one of the main priorities in marketing researches and its significance comes from the firm's desire and creation of strong brands to reach an unfailing competitive advantage and its products distinctions (Gil et al., 2007; Davis and Mentzer, 2008). In 1989, the scientific association of marketing defined brand equity as the additional value made by the name in the market through better profit margin or market's share of the product (Beristain \& Zorrilla, 2011). This value can be considered as the financial possession and a collection of desirable relations and conducts (Yasin et al. 2007). Regarding the above definition, the value of a brand is the result of the customers' perception influenced by many factors including sale promotions (Hyun, 2009). According to the researchers, sales promotions are primary means in marketing, which influence on brand equity. This issue becomes more important in retail industry because of its functions. In recent years, retail industry has encountered increasing competitive atmosphere and this adds to the significance of the study of factors lead to the distinction of the firms among others in the market. Considering the essentiality of the problem, in this study, the influence of sale promotions on the brand equity of ETKA chain stores is examined.

\section{Study literature}

\subsection{Brand Equity}

Among the numerous benefits of brand equity, we can point to the reduction of unnecessary expenses, profit growth, increase of the probability of the customer's choice, decrease of the advertising and sales expenses, successful development of the brand, consumers' readiness to pay additional prices, decrease of the company vulnerability against its rivals and crises and so on (Sriram et al., 2007). Generally, it can be said that brand equity indicates a source of competitive advantages (Yoo et al. 2000). Some people concluded that brand equity influences the future profits and long-term cash flux positively (Kim et al., 2005). The importance of brand equity has many benefits for brand-owning companies (Lambkin \& Muzellec, 2010; Biedenbach et al., 2011; Nyadzayo, et al., 2011). Solomon and Stewart stated that brand equity could provide competitive advantages for the company because it can give brand the power to gain and to keep bigger share in the market and sell with more profit margin and price (Jung \& Sung, 2008). Brand equity increases the chance of choosing a brand and leads to the customer's loyalty to one particular brand (Buil et al., 2013). One of the benefits of brand equity is the possibility of brand generalization to other products categories. In various studies, the following dimensions have been counted as the principal aspects of brand equity (Pappu et al., 2005, 2006; Konecnik \& Gartner, 2007; Boo et al., 2009; Tong \& Hawley, 2009; Lee \& Back, 2008; Menictas et al., 2012):

- Brand Loyalty: It can be defined as an extension of the customer's positive attitude towards a particular brand and it makes an obligation for further purchases (van Riel, et al., 2005; Morrison \& Eastburn, 2006). Tellis believes the effect of loyalty to the brand is more than other variables (Gil et al. 2007). Atilgan et al. (2005) supported this finding and stated that loyalty is the only factor, which influences brand equity directly. According to Aaker's model of brand equity, loyalty has been recalled as a financial lever for increasing marketing expenses, attracting new customers by giving them information, awareness and reassurance beside a time to answer competitive threats. He also has defined the index of loyalty to the brand in two ways: 1) an amount paid by the customer for a brand compared to other brands with similar advantages and 2) direct measuring of the customer's satisfaction and his intention for more purchases or ordering product or a service (Aaker, 1999).

- Perceived Quality: Zeithaml et al. (1996) explained the perceived quality as the customer understanding of the better quality of a product or a service than its rivals do. They revealed that the perceived quality was a part of brand equity, so high perceived quality drives the customer to select one brand among others (Herrmann, et al., 2007; Moorthy \& Hawkins, 2005). Therefore, by increasing the perceived quality by the customer, brand equity is also increased (Brady et al., 2008). The consumer's received quality is associated with the information assessment and loyalty to one brand. It also has a great impact on the consumer in the purchase stage (Gil et al., 2007). Gil et al. (2007) expressed that children experience the quality of those brands which their families use or suggest them 
and their understanding of the quality is in such a way that they consider their parents' knowledge of brands more reliable than their own. Therefore, the effect of this experience accompanies them in a long time. Aaker defined the perceived quality as the customer's perception of the total or better quality of a product or service regarding its special aim compared with other choices. In his model, he stated that the perceived quality may influences on brand equity through five different ways: 1) a reason to buy a brand 2) distinction of placement 3) additional price payment 4) attracting the interest of the distribution channel members to use a product with higher quality and finally 5) developing the brand (Aaker, 1991; Liao \& Cheng, 2012).

- Brand Awareness: Aaker (1991) defined this term as the consumer's ability in identifying or recalling a brand within a special product category. He mentioned in his model that brand awareness can be influential on brand equity through following factors:

1. Being a support for other associations that can be considered

2. Making a familiar relation

3. Being a sign of commitment constancy

Keller (2003) expressed that familiarity with brand plays an important role in the consumers' decision for purchasing and comes with the advantage of learning, attention and selection. According to Macdonald and Sharp (2003) awareness of brand is one of the major parts in the well-known techniques for advertisement influence hierarchy and one significant objective of communicative activities of marketing managers in such a way that they use this concept as an instrument to measure the effectiveness of marketing and advertising activities (Burmann et al., 2009). When a customer knows a large number of brands, which accord with his/her criteria, it seems unlikely that he/she strives to determine information about other unfamiliar brands and one of its important functions is increasing the perceived quality of the product or services by the consumer.

- Brand Association: Aker believed that brand awareness was closely associated with brand association. He defined brand association as a relationship in the memory with a brand. In his idea brand association may influence on brand equity in five ways: 1) helping information processing, 2) placement distinction, 3) a reason for purchasing a brand, 4) creating motivation and positive feeling and 5) development (Aaker, 1991).

According to Gil et al. (2007) association generates some sort of value and feeling for brands which extinguishes them among other existing brands. Moreover, the consumer records an image of a product in his/her memory which is bought or used by his family and that image does not merely include the name of the product but it may involve the shape of packing, design, particular picture or anything else that is easily associated. In addition, consumer's awareness and relationship with a positively strong associate is considered as an advantage for the brand and may lead to loyalty (Yoo and Danthu, 2001). Totally, brand generalization can be defined as the implementation of a special available brand to enter a new product category. Many people believe that preservation and development of brand equity often is a demanding and challenging activity. A vast perspective of different attitudes toward the effective factors on brand equity is necessary to enable us to develop properly.

\subsection{Sale Promotions}

In today`s market atmosphere, there are various ways, which may influence the creation and increase of brand equity through some marketing programs (Valette-Florence et al., 2011). Policies of distribution network, communicative strategies, pricing policies, promoting and other marketing activities may strengthen or weaken the brand (Chattopadhyay et al., 2010). In the case of knowing the method of marketing mix influencing specially policies associated with the product, pricing and promotions on the brand equity, these activities can be used in order to promote brand equity (Kim \& Hyun, 2011). In this 
regard, one of the important duties in marketing management is to determine the most effective combination of promotion (Palazón-Vidal \& Delgado-Ballester, 2005). Concerning the effect, promoting methods are different in such a way that each method has its own unique characteristics considered as a designator in selecting each one (Montaner \& Pina, 2011). A company must combine communicative means so mindfully to be able to present a balanced combination of promoting elements, something, which could help in achieving communicative and marketing aims (Palazón \& DelgadoBallester, 2009; Al-Fattal, 2010).

The promotions of communicative activities involve: advertisement, sale advancement, correspondence and public relations that inform and attract the target market to the availability and utility of the product (Kotler, 2000). In this study, by promotions, we mean the monetary and non-monetary sale promotions. According to Buil et al. (2013), sale promotions are key marketing instruments in communicative programs, which could influence brand equity. Hence, assessing Iranian brands equity and examining the influential factors on brands will be a weighty step in brand making and promoting Iranian brands in order to enter world markets to compete with foreign brands. Considering the importance of brand equity, we must concentrate more on the manner of creating value for marketing mix influencing for the brand so that the managers are able to increase their brand's value by using the achieved information and then by developing it promote their company's function. Besides, the results of this research will enable the marketing managers to detect the effective promoting factors on the brand equity for their brands from the viewpoint of the consumer to act for faster use of it. As it was mentioned, the brand equity is considered as a primary source of competitive advantage, which may decrease the company vulnerability against the crises and its rivals. It also influences on the firm's value and consequently its profits and cash flux. As the effective factors on the brand equity are evaluated, they can be used in order to increase inland brands equity. When Iranian brands obtain high equity, they will benefit from competitive advantage. Thus, it is possible to increase the presence of Iranian brands in the world markets, which in itself will cause the rise of some exports share in Iran. In addition, by increasing the supply of Iranian brands, the interest of the consumers also increases and this prevents the cycle of goods smuggling. On the other hand, in different studies it was shown that sale promotions and advertisements include a considerable share of the company's expenses (Buil et al., 2013). It means that if these expenses aren't effective a big share of the company sources is wasted.

\section{Hypotheses}

- Monetary promotions influence brand association

- Monetary promotions influence brand perceived quality

- Monetary promotions influence brand awareness

- Non-monetary promotions influence brand association

- Non-monetary promotions influence brand perceived quality

- Non-monetary promotions influence brand awareness

- The perceived quality influences brand loyalty

- Brand association influences brand loyalty

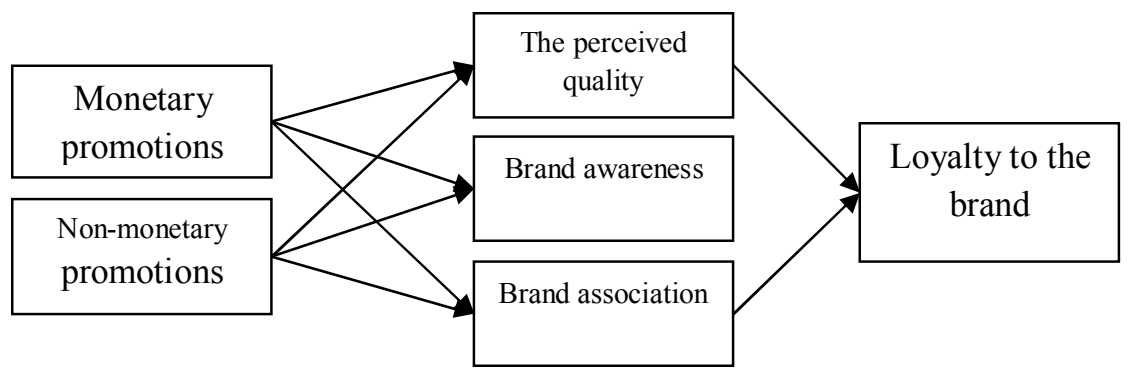

Fig. 1. Research Conceptual Model 


\section{Methodology}

The present research regarding its aim stands within the category of applicable researches and concerning the way of getting and analyzing data is a descriptive kind of research. It has used a structural equations modeling in order to analyze data. As it was mentioned before, the aim of this study is the examination of sale promotions impact on the brand equity of ETKA chain stores in Tehran. Therefore, the target society in this study involves customers of ETKA stores in Tehran. The method of gathering data was distribution of the questionnaires among the customers of these stores whom answered our questions and were considered as the participants in this study. Since the target society was unlimited, 500 questionnaires were distributed from which 490 ones were completed and analyzed. The questionnaire used here had two parts. The first section included questions of age, gender, education and in the second part, 27 questions were used for examining independent and dependent study variables. In order to examine brand awareness, the perceived quality, brand association and brand loyalty in order 5, 4, 9 and 3 questions were used. Likewise, for examining sale promotions 6 questions were used, 3 of which were related to monetary promotions and the other 3 were related to nonmonetary promotions of the criteria used by Buil et al. (2013). All these questions in Likert's range, from 5 (completely agreed) to 1 (completely disagreed) were pondered over. In this research the reliability of the questionnaire using Cronbach Alpha method has been as the following: 0.91 for sale promotions, 0.90 for brand awareness, 0.93 for brand association, 0.87 for the perceived quality, 0.88 for brand loyalty and for the whole questionnaire it was 0.89 .

\subsection{Structural Equations Modeling}

In order to evaluate the suggested model, in this paper we used Structural equations modeling (SEM). Before examining the structural coefficient, the model's fitness was reconsidered. The primary model fitness has been reported in Table 1 based on the fitness indices used in this study. Since the amount of theses indices of the primary model signified that the suggested model needed correction and improvement, in the next stage regarding the corrected indices, in the Amos 18 output, Co-variance path was added to the model between visual and informational elements. After applying the modifications another analysis was done on the data, the results of which related to the fitness indices has been brought in the row of the second (final) model in table 1. As it was expected, fitness indices indicate an improvement in the second model fitness so they are acceptable.

\section{Findings}

Considering the analysis of data the respondents examined in this research involved a group of 287 men $(58.5 \%)$ and a group of 203 women $(41.5 \%)$. Of this population 125 people $(25.5 \%)$ were under the age 30,142 ones $(29 \%)$ between $30-39,104$ ones $(21.2 \%)$ between $40-49$, and finally 119 people (24.2 $\%)$ over 50 .

\section{Table 1}

Fitness indices for models $1 \& 2$

\begin{tabular}{ccccccccccc}
\hline Model's fitness indices & $\mathrm{X}^{2}$ & $\mathrm{Df}$ & $\mathrm{X}^{2} / \mathrm{DF}$ & GFI & AGFI & IFI & TLI & CFI & NFI & EMSEA \\
\hline 1 & 656.713 & 346 & 1.898 & .779 & .701 & .821 & .751 & .801 & .871 & .088 \\
2 & 561.212 & 327 & 1.716 & .913 & .902 & .95 & .941 & .931 & .90 & .034 \\
Independence model & 9721.074 & 363 & 26.779 & .21 & .182 & - & - & - & - & .235 \\
\hline
\end{tabular}

The amounts of 561.212 for $\mathrm{CMIN}$ and $\mathrm{P}=0.001$ for significance gives us satisfactory results, yet $\mathrm{DF}$ also plays an important role here. For relative indices, we may point to the amount of 1.71 for CMIN/DF, which shows an acceptable condition. The amount of 0.034 for RMSEA for the codified functional model signifies the acceptability of the model. In the above table, the TLI index is 0.941 and 0.931 for CFI and since these amounts are close and more than 0.90 based on these indices the codified 
model seems acceptable. For the second model, NFI was 0.90 and IFI was 0.95 , both as acceptable amounts. The amounts of the total fitness indices brought in the above table show that the measuring model of this research is satisfactorily credible. Likewise, the obtained amounts 0.913 and 0.902 in order for GFI and AGFI means that the model is appropriately fitted.

\section{Table 2}

Structural models of the paths and their standard coefficients in the final model

\begin{tabular}{llccl}
\hline Hyp. & Path & $\beta$ & Sig. & Sig. \\
\hline 1 & Monetary promotions $\rightarrow$ brand association & 0.223 & 0.011 & Confirmed \\
2 & Monetary promotions $\rightarrow$ quality & 0.256 & 0.001 & Confirmed \\
3 & Monetary promotions $\rightarrow$ brand awareness & 0.511 & 0.000 & Confirmed \\
4 & Non-monetary promotions $\rightarrow$ brand association & 0.331 & 0.001 & Confirmed \\
5 & Non-monetary promotions $\rightarrow$ quality & 0.412 & 0.000 & Confirmed \\
6 & Non-monetary promotions $\rightarrow$ brand awareness & 0.32 & 0.000 & Confirmed \\
7 & Perceived quality $\rightarrow$ brand loyalty & 0.46 & 0.000 & Confirmed \\
8 & Brand association $\rightarrow$ Brand loyalty & 0.31 & 0.001 & Confirmed \\
\hline
\end{tabular}

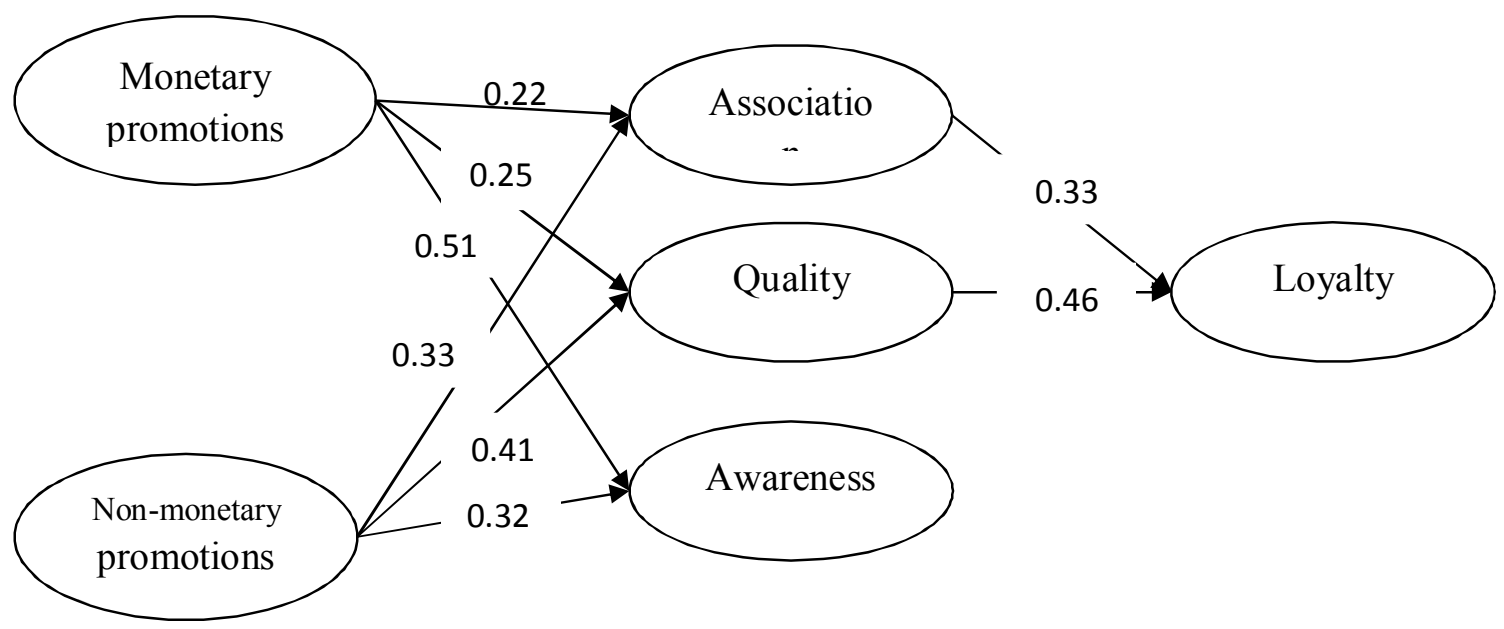

Fig. 2. Research model

The achieved results from testing the research model indicate that regression coefficient of monetary promotions on brand association is 0.223 and since it is the significant amount of 0.011 less than the significance level $\alpha=0.05$, here $\mathrm{H}_{0}$ is rejected and it can be concluded that monetary promotions have a positive and significant effect on brand association. The results also show that the regression coefficient of the effect of monetary promotions on the perceived quality is 0.256 as a significant amount of 0.001 which is less than significance level of $\alpha=0.05$, it can be said that monetary promotions affect the perceived quality. In the same way the regression coefficient of monetary promotions' effect on brand awareness is 0.511 , since it is a significant amount of 0.000 less than $\alpha=0.05, \mathrm{H}_{0}$ is rejected and we can say that monetary promotions affect brand awareness positively and significantly. Other results indicate that regression coefficient of non-monetary promotions' effect on the brand association is 0.331 , the significant amount of 0.001 less than $\alpha=0.05$, here again $\mathrm{H}_{0}$ is not accepted; then non-monetary promotions influence brand association. The rest of the research findings are as the following: regression coefficient of non-monetary promotions' effect on the quality is 0.412 , the amount of 0.000 less than $\alpha=$ 0.05 , therefore $\mathrm{H}_{0}$ is rejected and this means that non-monetary promotions have positive effect on the quality. Regression coefficient of non-monetary promotions on brand awareness is 0.32 , the significant 
amount of 0.000 which leads to the rejection of $\mathrm{H}_{0}$. In other words non-monetary promotions influence brand awareness significantly. Regression coefficient of the seventh hypothesis is 0.46 and regarding the significant amount of this path it can be concluded that the perceived quality has a positive effect on brand loyalty. The eighth hypothesis is confirmed considering the regression coefficient of 0.31 and the significance amount of 0.001 , consequently brand association affects loyalty positively.

\section{Discussion and Conclusion}

As it was stated in the present research we examined the effectiveness of sale promotions on the brand equity aspects in ETKA chain stores in Tehran continued by considering hypotheses which were formed based on theoretical principles. The first thing that we observed in the results of this study was the positive effect of monetary promotions on brand association which is consistent with findings of Kim and Hyun (2011). The second hypothesis examined the influence of monetary promotions on the perceived quality of the stores and was supported. The result of this hypothesis was similar to what Buil et al. (2013) had reached. The researchers showed in their study that monetary promotions affected negatively yet significantly on the quality. In the next stage, we reviewed the effect of monetary promotions on brand awareness, something which was accepted regarding the amount of regression coefficient and significance. Our findings here agreed with the results of the studies of Buil et al. (2013) and Kim and Hyun (2011). The effectiveness of non-monetary promotions on brand association was another result of this study. This conformed to what Chattopadhyay et al. (2010) reached to. The study also examined the effects of non-monetary promotions on the perceived quality. By considering regression coefficient between these two variables and significance this hypothesis was accepted, being compatible with the results of Buil et al. (2013) study. The sixth hypothesis has reconsidered the effect of non-monetary promotions on the brand awareness; again concerning the regression coefficient and significance it was admitted. Gil et al. (2007) reached at similar findings. The effectiveness of quality on the brand loyalty was confirmed too, being in harmony with Jinfeng and Zhilong (2009) studies. The opinion of the researchers is that the more the perceived quality the more will be the customer's loyalty to the brand. The last hypothesis dealt with examining the influence of brand association on the loyalty. What the study achieved based on the regression coefficient and significance amount was the acceptance of the hypothesis. Therefore, there is a similarity between our findings and that of Buil et al. (2013).

\section{Implications}

The first hypothesis of the study showed that monetary promotions influence on brand association. Considering this issue the stores' managers should focus strongly on taking suitable strategies in their discounts or those cases, which lead to price reduction. In fact, the benefits that a customer attains as the result of his purchasing from a store must be taken into account in the pricing process. In addition, appropriate pricing for goods, which have a big share in the family basket can improve word of mouth (WOM) advertisement for the store. It was also revealed that monetary promotions influence the quality and brand awareness. Customer's positive perception of this issue can cause their WOM advertisement. Based on this, the managers besides emphasizing on the appropriateness of their goods' prices can infuse this belief that by purchasing from our stores you will get a high quality product by paying proper cost. Another noticeable points in the study were in the fourth, fifth and sixth hypotheses which had examined the effect of non-monetary promotions on the brand association, quality and awareness. We got from these examinations that all three hypotheses were confirmed. Having a look at this matter it can be said that in order to promote their stores' brand equity it is better that the managers of these stores send some gifts to their customers in particular days. According to the results of the seventh and eighth hypotheses we suggest that a special attention is paid to the quality of the presented services in the store. One of the factors which have a considerable effect on the quality in retail dealings and chain stores is human workforce and his services. In other words, presenting proper or improper services by the salesperson and other staff can leave a desirable or undesirable image of the company in the mind of the customer. For this reason, it is suggested that through encouraging policies or presenting necessary 
training the level of human services' quality is increased. On the other side, at the time of employment we can engage more qualified and appropriate people considering this factor.

\section{References}

Aaker, D. A. (1996). Measuring brand equity across products and markets. California management review, 38(3), 103.

Aaker, D. A. (2009). Managing Brand Equity. Simon and Schuster.

Al-Fattal, A. (2010). Understanding student choice of university and marketing strategies in Syrian private higher education. University of Leeds.

Atilgan, E., Aksoy, S., \& Akinci, S. (2005). Determinants of the brand equity: a verification approach in the beverage industry in Turkey. Marketing intelligence \& planning, 23(3), 237-248.

Baumgarth, C., \& Schmidt, M. (2010). How strong is the business-to-business brand in the workforce? An empirically-tested model of 'internal brand equity' in a business-to-business setting. Industrial Marketing Management, 39(8), 1250-1260.

Juan Beristain, J., \& Zorrilla, P. (2011). The relationship between store image and store brand equity: A conceptual framework and evidence from hypermarkets. Journal of Retailing and Consumer Services, 18(6), 562-574.

Biedenbach, G., Bengtsson, M., \& Wincent, J. (2011). Brand equity in the professional service context: Analyzing the impact of employee role behavior and customer-employee rapport. Industrial Marketing Management, 40(7), 1093-1102.

Boo, S., Busser, J., \& Baloglu, S. (2009). A model of customer-based brand equity and its application to multiple destinations. Tourism Management, 30(2), 219-231.

Brady, M. K., Cronin Jr, J. J., Fox, G. L., \& Roehm, M. L. (2008). Strategies to offset performance failures: The role of brand equity. Journal of Retailing, 84(2), 151-164.

Buil, I., de Chernatony, L., \& Martínez, E. (2013). Examining the role of advertising and sales promotions in brand equity creation. Journal of Business Research, 66(1), 115-122.

Burmann, C., Jost-Benz, M., \& Riley, N. (2009). Towards an identity-based brand equity model. Journal of Business Research, 62(3), 390-397.

Calvo-Porral, Cristina, Martinez-Fernández, Valentín-Alejandro, Juanatey-Boga, Oscar, LévyCalvo-Porral, C., Martinez-Fernández, V. A., Juanatey-Boga, O., \& Lévy-Mangín, J. P. (2013). What matters to store Brand Equity? An approach to Spanish large retailing in a downturn context. Investigaciones Europeas de Dirección y Economía de la Empresa, 19(3), 136-146.

Chattopadhyay, T., Dutta, R. N., \& Sivani, S. (2010). Media mix elements affecting brand equity: A study of the Indian passenger car market. IIMB Management Review, 22(4), 173-185.

Davis, D. F., \& Mentzer, J. T. (2008). Relational resources in interorganizational exchange: the effects of trade equity and brand equity. Journal of Retailing,84(4), 435-448.

Gil, R. B., Andrés, E. F., \& Salinas, E. M. (2007). Family as a source of consumer-based brand equity. Journal of Product \& Brand Management, 16(3), 188-199.

Herrmann, A., Huber, F., Shao, A. T., \& Bao, Y. (2007). Building brand equity via product quality. Total quality management, 18(5), 531-544.

Hyun, S. S. (2009). Creating a model of customer equity for chain restaurant brand formation. International Journal of Hospitality Management, 28(4), 529-539.

Jinfeng, W., \& Zhilong, T. (2009). The impact of selected store image dimensions on retailer equity: evidence from 10 Chinese hypermarkets. Journal of Retailing and Consumer Services, 16(6), 486494.

Jung, J., \& Sung, E. (2008). Consumer-based brand equity: Comparisons among Americans and South Koreans in the USA and South Koreans in Korea. Journal of Fashion Marketing and Management, 12(1), 24-35.

Keller, K. L., Parameswaran, M. G., \& Jacob, I. (2011). Strategic brand management: Building, measuring, and managing brand equity. Pearson Education India. 
Keller, K. L., \& Lehmann, D. R. (2006). Brands and branding: research findings and future priorities. Marketing Science, 25(6), 740-759.

Kim, J. H., \& Hyun, Y. J. (2011). A model to investigate the influence of marketing-mix efforts and corporate image on brand equity in the IT software sector. Industrial Marketing Management, 40(3), 424-438.

Kim, H. B., \& Kim, W. G. (2005). The relationship between brand equity and firms' performance in luxury hotels and chain restaurants. Tourism management, 26(4), 549-560.

Konecnik, M., \& Gartner, W. C. (2007). Customer-based brand equity for a destination. Annals of tourism research, 34(2), 400-421.

Kotler, P. (2000). Marketing management. Englewood Cliffs, N.J.: Prentice Hall;

Kundu, P., Kurkarni, A., \& Murthy, N.K. (2008). Advertising and firm value: Mapping the relationship between advertising, Profitability and Business Strategy in India.

Lambkin, M. C., \& Muzellec, L. (2010). Leveraging brand equity in business-to-business mergers and acquisitions. Industrial Marketing Management, 39(8), 1234-1239.

Lee, J. S., \& Back, K. J. (2010). Reexamination of attendee-based brand equity. Tourism Management, 31(3), 395-401.

Lee, J. S., \& Back, K. J. (2008). Attendee-based brand equity. Tourism Management, 29(2), 331-344.

Liao, S., \& Cheng, C. C. (2014). Brand equity and the exacerbating factors of product innovation failure evaluations: A communication effect perspective. Journal of Business Research, 67(1), 2919-2925.

Lin, C. H., \& Kao, D. T. (2004). The impacts of country-of-origin on brand equity.Journal of American Academy of Business, 5(1/2), 37-40.

Macdonald, E. K., \& Sharp, B. M. (2000). Brand Awareness Effects on Consumer Decision Making for a Common, Repeat Purchase Product:: A Replication. Journal of business research, 48(1), 515.

Menictas, C., Wang, P. Z., \& Louviere, J. J. (2012). Assessing the validity of brand equity constructs. Australasian Marketing Journal (AMJ), 20(1), 3-8.

Moorthy, S., \& Hawkins, S. A. (2005). Advertising repetition and quality perception. Journal of Business Research, 58(3), 354-360.

Montaner, T., \& Pina, J. M. (2011). The effect of promotion type and benefit congruency on brand image. Journal of Applied Business Research (JABR),24(3), 15-28.

Morrison, M., \& Eastburn, M. (2006). A study of brand equity in a commodity market. Australasian Marketing Journal (AMJ), 14(1), 62-78.

Nyadzayo, M. W., Matanda, M. J., \& Ewing, M. T. (2011). Brand relationships and brand equity in franchising. Industrial Marketing Management, 40(7), 1103-1115.

Palazón-Vidal, M., \& Delgado-Ballester, E. (2005). Sales promotions effects on consumer-based brand equity. International Journal of Market Research, 47(2), 179-204.

Palazon, M., \& Delgado-Ballester, E. (2009). Effectiveness of price discounts and premium promotions. Psychology \& Marketing, 26(12), 1108-1129.

Pappu, R., Quester, P. G., \& Cooksey, R. W. (2006). Consumer-based brand equity and country-oforigin relationships: some empirical evidence. European Journal of Marketing, 40(5/6), 696-717.

Seo, S., \& Jang, S. S. (2013). The roles of brand equity and branding strategy: a study of restaurant food crises. International Journal of Hospitality Management, 34, 192-201.

Simon, C. J., \& Sullivan, M. W. (1993). The measurement and determinants of brand equity: a financial approach. Marketing science, 12(1), 28-52.

Sriram, S., Balachander, S., \& Kalwani, M. U. (2007). Monitoring the dynamics of brand equity using store-level data. Journal of Marketing, 71(2), 61-78.

Sweeney, J., \& Swait, J. (2008). The effects of brand credibility on customer loyalty. Journal of Retailing and Consumer Services, 15(3), 179-193.

Tong, X., \& Hawley, J. M. (2009). Measuring customer-based brand equity: empirical evidence from the sportswear market in China. Journal of Product \& Brand Management, 18(4), 262-271. 
Valette-Florence, P., Guizani, H., \& Merunka, D. (2011). The impact of brand personality and sales promotions on brand equity. Journal of Business Research, 64(1), 24-28.

Van Riel, A. C., Pahud de Mortanges, C., \& Streukens, S. (2005). Marketing antecedents of industrial brand equity: An empirical investigation in specialty chemicals. Industrial Marketing Management, 34(8), 841-847.

Villarejo-Ramos, A. F., \& Sánchez-Franco, M. J. (2005). The impact of marketing communication and price promotion on brand equity. The Journal of Brand Management, 12(6), 431-444.

Wang, P. Z., Menictas, C., \& Louviere, J. J. (2007). Comparing structural equation models with discrete choice experiments for modelling brand equity and predicting brand choices. Australasian Marketing Journal (AMJ), 15(2), 12-25.

Yasin, N. M., Noor, M. N., \& Mohamad, O. (2007). Does image of country-of-origin matter to brand equity?. Journal of Product \& Brand Management, 16(1), 38-48.

Yoo, B., \& Donthu, N. (2001). Developing and validating a multidimensional consumer-based brand equity scale. Journal of business research, 52(1), 1-14.

Yoo, B., Donthu, N., \& Lee, S. (2000). An examination of selected marketing mix elements and brand equity. Journal of the Academy of Marketing Science,28(2), 195-211.

Zeithaml, V. A., Berry, L. L., \& Parasuraman, A. (1996). The behavioral consequences of service quality. the Journal of Marketing, 60(2), 31-46. 